GRASAS Y ACEITES, 60 (5),

\title{
Physico-chemical attributes of seed oil from drought stressed sunflower (Helianthus annuus L.) plants
}

\author{
By Qasim Ali, ${ }^{1}$ Muhammad Ashraf ${ }^{1}$ and Farooq Anwar ${ }^{* 2}$ \\ ${ }^{1}$ Department of Botany, University of Agriculture, Faisalabad, 30840, Pakistan \\ ${ }^{2}$ Department of Chemistry \& Biochemistry, University of Agriculture, Faisalabad, 30840, Pakistan \\ ( ${ }^{*}$ Corresponding Author: fqanwar@yahoo.com)
}

\begin{abstract}
RESUMEN
Atributos físico-químico en aceite de semilla de plantas de girasol (Helianthus annuus L.) sometidas a estrés por sequia.
\end{abstract}

El efecto de las condiciones de déficit de agua sobre las características cualitativas y cuantitativas de semilla de girasol y aceites de semilla fueron evaluadas. Dos cultivos de girasol (Gulshan-98 y Sun Cross) fueron sembrados en el campo. El tratamiento de estrés hídrico fue aplicado en el estado vegetativo y reproductivo. El análisis de la semilla de girasol mostro que el contenido en aceite disminuyo significativamente ( $p \leq 0.05$ ) (un descenso del $10,52 \%$ respecto al control) debido al estrés hídrico cuando se impone en ambos estado de crecimiento. Ambos cultivos de girasol mostraron respuestas diferenciadas al estrés hídrico con respecto a los contenidos de los ácidos oleico y linoleico. Una correlación negativa significativa entre los ácidos oleico y linoleico fue observada en cv. Gulshan-98 bajo condiciones de déficit de agua en comparación con Suncross en la que tal efecto del estres hídrico sobre los ácidos oleico y linoleico no fue obsevado. Las condiciones de déficit de agua causan una reducción en el ácido linoleico en Gulshan-98, mientras que permanece inalterado en Suncross. Los contenidos de ácido esteárico aumentaron en cv. Gulshan-98 debido a la sequia, mientras que no se observo efecto del estrés hídrico sobre el contenido de ácido palmítico en el aceite de ambos cultivos de girasol. En general, los ácidos grasos poliinsaturado del aceite permanecen sin cambios en condiciones de estrés hídrico o en plantas regadas normalmente de ambos cultivo, sin embargo los ácidos grasos saturados incrementaron en Gulshan-98. Los contenidos de tocoferoles totales 0 individuales $(\alpha, \gamma$, and $\delta$ ) en aceite de semilla se incrementaron significativamente con la aplicación de estrés hídrico en ambos cultivos. Una evaluación de las características físicas y químicas de ambos cultivos de girasol revelan que el estrés por sequia causa un marcado incremento en el contenido de materia insaponificable (18,75\% con respecto al control) y un descenso del índice de yodo $(5,87 \%$ respecto al control), aunque el índice de saponificación, densidad, peso específico y índice de refracción permanecen sin cambios.

PALABRAS CLAVES: Aceite de semilla - Ácidos grasos - Etapas de crecimiento - Girasol - Sequia - Tocoferoles.

\section{SUMMARY}

Physico-chemical attributes of seed oil from drought stressed sunflower (Helianthus annuus L.) plants.

The effects of water deficit conditions on the qualitative and quantitative characteristics of sunflower seed and seed oils were assessed. Two sunflower cultivars (Gulshan-98 and Suncross) were sown in the field. The water stress treatment was applied at the vegetative or the reproductive stage. Analysis of the sunflower seed showed that the oil content decreased (a decline of $10.52 \%$ relative to the control) significantly $(p \leq 0.05)$ due to water stress when imposed at either of the growth stages. Both of the sunflower cultivars studied showed differential responses to water stress with respect to oil oleic and linoleic acid contents. A significant negative correlation in oil oleic and linoleic acid was observed in cv. Gulshan-98 under water deficit conditions as compared to Suncross in which no such effect of water stress on oleic and linoleic acid was observed. Water deficit conditions caused a reduction in linolenic acid in Gulshan-98, whereas it remained unaffected in Suncross. The stearic acid content increased in cv. Gulshan-98 due to drought, whereas no effect due to water stress was observed on oil palmitic acid content in either sunflower cultivar. Overall, oil unsaturated fatty acids remained unchanged in the drought stressed or normally irrigated plants of both cultivars but saturated fatty acid increased in Gulshan-98. Individual $(\alpha, \gamma$, and $\delta)$ and total tocopherol contents in the seed oil increased significantly with the application of water stress in both cultivars. An assessment of the physical and chemical characteristics of the oils of both sunflower cultivars revealed that drought stress caused a marked increase in the content of un-saponifiable matter $(18.75 \%$ with respect to the control) and a decrease in iodine value $(5.87 \%$ with respect to the control), but saponifcation value, density, specific gravity and refractive index remained unchanged.

KEY-WORDS: Sunflower - Drought - Growth stages Seed oil - Fatty acids - Tocopherols.

\section{INTRODUCTION}

The vital role of the sunflower crop depends mainly on the characteristics of the oil produced, which can be used directly or after processing in food and non-food industries (Vermeercsh, 1996). Sunflower oil contains four important fatty acids, namely palmitic (16:0), stearic (18:0), oleic (18:1), and linoleic (18:2) acids (Baydar and Erbas, 2005). In common varieties, oleic acid is transformed into linoleic acid by the $\Delta-12$ desaturase (Monotti, 2003), so the differential transformation can cause differential accumulation of oleic acid in different varieties. One potential reason for variability in oleic acid content may be water stress soon after the initiation of flowering (Monotti, 2003).

It is known that genetic and environmental factors play an important role in the economic outcome of an oilseed crop and can affect the oil 
yield and quality of its grain/seed production. Trials have shown that unfavorable conditions, especially drought, might alter the seed composition and related qualities (Nel, 2001; Anwar et al., 2006). Lack of water during all stages of growth and development is one of the limiting factors for seed growth and can influence the composition of its oil (Flagella et al., 2002). According to a number of reports, it is evident that the stress tolerance of most plant species varies at different growth stages (Kefale and Ranamukhaarachchi, 2006; Li-Ping et al., 2006; Nam et al., 2001).

The effect of water availability on the final fatty acid composition of the oil with particular reference to the content of major fatty acids such as oleic acid and linoleic acid has mainly been examined in sunflower genotypes in response to water stress during different phases of crop cycles (Talha and Osman, 1975; Flagella et al., 2000; Baldini et al., 2002). It has been demonstrated that stopping irrigation from flowering to physiological maturity enhances the percentage of oleic acid in sunflower seeds compared to those from well watered regimes (Flagella et al., 2000). An increase in oleic /linoleic acid ratio under water stress was also reported by Talha and Osman (1975). However, Santonoceto et al. (2003) have shown that sometimes oleic acid content per sunflower seed may increase with an increase in water availability which ultimately increases the oleic/linoleic acid ratio; while in contrast, Salera and Baldini (1998) observed no effect of water management on oleic acid content in sunflowers. Such contrasting reports led us to investigate whether or not a change in the composition of sunflower seed oil takes place due to drought stress.

Tocopherols, which are the most powerful natural fat soluble antioxidants (vitamin E), exist as $\alpha-, \beta-, \gamma-$, and $\delta$ - tocopherols (Slover, 1970). Tocopherol composition in the seeds shows genetic and phenotypic variability (Demurin, 1996), but information on whether or not drought stress can alter the tocopherol content of sunflower oil is lacking in the literature.

The aim of this research was to determine whether full or limited water supply to two sunflower cultivars could alter their oil yield and quality. The effects of drought stress on the composition of fatty acids, tocopherols and other physico-chemical properties of the sunflower oil were also evaluated. The work reported here is the first attempt to examine the effect of drought stress on the quality of sunflower oil from the seeds of plants that were subjected to stress at different growth stages i.e. vegetative and reproductive stages.

\section{Materials and Methods}

Two sunflower lines, Gulshan-98 (dwarf) and Suncross (tall) were used in the present study. The seeds of both lines were obtained from the regional office of Pakistan Seed Council, Faisalabad, Pakistan. The study comprised the following experimentation:

\subsection{Field experiment}

The effect of drought on sunflowers was assessed under field conditions. The samples were planted at the Research Area of the Department of Botany, University of Agriculture, Faisalabad, Pakistan. All physico-chemical characteristics of the soil used were determined using standard procedures (Dewis and Freitas, 1970).

The experiment was laid out in a split plot design with three replicates of each experimental unit. Water stress was applied at the vegetative stage or the reproductive stage of plant growth along with a control (normal irrigation with three inches water depth approximately $3900 \mathrm{~L} / 50 \mathrm{~m}^{2}$ ) for each time. The first irrigation was applied 15 days after emergence to all the three main plots. The second irrigation was applied 25 days after the first one except for the plants which were subjected to water stress at the vegetative stage. The third irrigation was applied at the time of head formation (twenty five days after the second one) except for the plants which were subjected to water stress at the reproductive stage. The last irrigation was applied to all plants at the seed filling stage.

\subsection{Oil extraction}

Dried seeds $(100 \mathrm{~g})$ of each experimental unit in each batch were crushed and fed to a Soxhlet extractor fitted with one liter round bottom flask and a condenser. The extraction was executed with 0.5 $\mathrm{L}$ of $n$-hexane on a water bath for 6-7 $\mathrm{h}$. The solvent was removed under vacuum in a rotary evaporator (Eyela, N. N. Series, Rikakikai Co. Ltd., Tokyo, Japan) equipped with an aspirator and a digital water bath and the percentage of oil was recorded.

\subsection{Analysis of the extracted oil}

\section{Physico-chemical properties of oil}

Determinations of the density, refractive index, iodine value, saponification value and unsaponifiable matter of the extracted oil were carried out according to the AOCS (1997) methods.

\section{Tocopherol content}

The tocopherol content ( $\alpha, \gamma$ and $\delta$ ) in the sunflower seed oil was analyzed by HPLC following the method described by Lee et al. (2003). The peak areas were recorded and calculated by a computer with SRI peak simple chromatography data acquisition and integration software (SRI Instrument, Torrance, CA).

\section{Fatty Acid Composition}

Fatty acid methyl esters (FAMEs) were prepared according to the IUPAC (1987) method 2.301 and fatty acids were quantified using a SHIMADZU 
(Kyoto, Japan) gas chromatograph model GC-17A, fitted with a methyl-lignocerate-coated polar capillary column SP-2330 $(30 \mathrm{~m} \times 0.32 \mathrm{~mm} \times 0.20$ um; Supelco, Inc., Bellefonte, PA., USA.) and a flame ionization detector. Nitrogen was used as a

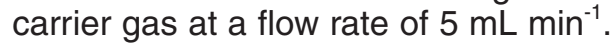

\subsection{Statistical Analysis}

Three samples of each treatment were taken and analyzed individually in triplicate. Analysis of variance of the data for each attribute was computed using the MSTAT Computer Program (1989). The Duncan's New Multiple Range test at 5\% level of probability was used to test the differences among mean values (Steel and Torri, 1986).

\section{RESULTS}

The imposition of water stress at the vegetative or the reproductive stage caused a significant reduction in oil yield, as compared to well watered plants. Both sunflower lines differed significantly in seed oil content. The cultivar Suncross had a higher achene oil content as compared to Gulshan-98 both under well watered and water deficit conditions (Table 1).

An analysis of variance showed that drought stress imposed at different growth stages had no significant effect on oil palmitic acid content; however, oil stearic acid content increased significantly due to the imposition of water stress at different growth stages and this effect was observed only in cv. Gulshan-98 but no in cv. Suncross. This maximum increase in oil stearic acid content was observed when water stress was applied at the reproductive stage. Both cultivars differed significantly in oil palmitic acid content but only under well watered conditions. However, the cultivar difference in oil stearic acid content was not observed under stress or non-stress conditions. A significantly higher content of palmitic acid was observed in Cv. Gulshan-98 than in cv. Suncross under well watered conditions (Table 1).

The imposition of water stress at the vegetative or the reproductive stage significantly ( $p \leq 0.001$ ) affected the oil's oleic acid proportion in both sunflower cultivars (Table 1). Oleic acid increased significantly in Gulshan-98 due to the imposition of water stress at different growth stages and a maximum increase in this fatty acid was observed when water stress was applied at the reproductive stage. However, in cv. Suncross, the oil's oleic acid content decreased significantly due to the imposition of water stress at either growth stage. Both cultivars differed significantly in the oil's oleic acid content under well watered conditions. The cultivar Suncross contained higher levels of oleic acid than the cv. Gulshan-98.

A marked inhibitory effect of water stress applied at the reproductive stages was observed in the oil's linoleic acid content in cultivar Gulshan-98; however, this inhibitory effect of water stress on the oil's linoleic acid content was not observed in cv. Suncross when water stress applied at either growth stages. Both cultivars differed significantly in the linoleic acid content of the oil but only under water stress conditions applied at the vegetative stage (Table 1)

The oil's linolenic acid content of the cultivar Gulshan-98 decreased significantly $(p \leq 0.05)$ due to imposition of water stress at the vegetative or the reproductive stage. However, it remained unaffected in cv. Suncross due to water stress imposed at either growth stage. A maximum decrease in linolenic acid content was observed in cv. Gulshan-98 due to water stress when applied at the reproductive stage. The cultivars differed significantly in the oil's linolenic acid content when water stress was applied at the vegetative or the reproductive growth stage. A significantly higher amount of linolenic acid was observed in the cv. Suncross as compared to the cv. Gulshan-98 (Table 1).

The oleic acid/linoleic acid ratio of the oil was significantly $(p \leq 0.001)$ affected by water stress in both sunflower cultivars and the maximum value was observed in plants that were stressed at the reproductive stage. Significantly higher ratios were recorded in cv. Suncross as compared to those in Gulshan-98 under all different water regimes (Table 1).

No significant effect of drought was observed on the contents of un-saturated fatty acids in both cultivars; however, total saturated fatty acids increased slightly in the cv. Suncross when water stress was applied at either growth stage. Cultivars did not differ significantly with regards to unsaturated fatty acids; however, the cv. Gulshan98 had significantly $(p \leq 0.05)$ higher levels of saturated fatty acids as compared to Suncross but only under non-stress conditions (Table 1).

The imposition of water stress at the vegetative or the reproductive stage of plants significantly $(p \leq$ 0.001 ) increased the $\alpha$-tocopherol in the seed oil of cv. Suncross, however, in the cultivar Gulshan-98 this increase in $\alpha$-tocopherol was observed only when water stress was applied at the reproductive stage. The cultivar Suncross had higher values of $\alpha$-tocopherols than those in Gulshan-98 under water stress conditions (Table 1).

The concentrations of $\gamma$ - and $\delta$-tocopherols increased significantly $(p \leq 0.001)$ with the imposition of water stress in both cultivars, particularly in plants stressed at the reproductive stage (Table 1). The cultivars did not differ significantly with regard to their contents of $\gamma$ - and $\delta$-tocopherols. The total tocopherol contents in the seed oil of both cultivars increased significantly due to water stress as well as the maximum content observed in the seed oil from the plants of both cultivars when stressed at the reproductive stage. The cultivar Suncross had higher total tocopherol 
Table 1

Seed oil content and composition of different fatty acids and tocopherols of the seed oil of two sunflower lines when subjected to water stress at different growth stages $(n=3)$

\begin{tabular}{|c|c|c|c|}
\hline & Normal irrigation & $\begin{array}{l}\text { Water stress } \\
\text { at vegetative stage }\end{array}$ & $\begin{array}{l}\text { Water stress } \\
\text { at reproductive stage }\end{array}$ \\
\hline \multicolumn{4}{|c|}{ Seed oil (\%) (LSD 5\% = 0.92) } \\
\hline Gulshan 98 & a $36.77 \mathrm{y} \pm 1.25$ & b $33.20 y \pm 1.40$ & b $33.97 \mathbf{y} \pm 1.39$ \\
\hline \multirow{2}{*}{\multicolumn{4}{|c|}{$\begin{array}{c}\text { a } 39.13 \times \pm 1.63 \\
\text { Palmitic acid (LSD } 5 \%=3.34)\end{array}$}} \\
\hline & & & \\
\hline Gulshan 98 & a $8.60 x \pm 1.49$ & a $8.66 x \pm 1.46$ & a $8.99 x \pm 1.18$ \\
\hline \multirow{2}{*}{\multicolumn{4}{|c|}{ Stearic acid (LSD $5 \%=1.61$ ) }} \\
\hline & & & \\
\hline Gulshan 98 & a $8.15 x \pm 0.20$ & ab $8.96 x \pm 0.67$ & b $10.51 x \pm 0.85$ \\
\hline Suncross & & & a $9.56 x \pm 0.45$ \\
\hline \multicolumn{4}{|c|}{ Oleic acid (LSD $5 \%=3.66)$} \\
\hline Suncross & a $53.28 \mathrm{x} \pm 1.89$ & b $49.05 x \pm 2.98$ & $\begin{array}{l}\text { b } 49.17 x \pm 5.26 \\
\text { b } 49.05 x \pm 1.49\end{array}$ \\
\hline \multicolumn{4}{|c|}{ Linoleic acid (LSD $5 \%=3.50$ ) } \\
\hline Gulshan 98 & a $25.53 x \pm 1.26$ & a $27.04 x \pm 2.33$ & b $22.99 x \pm 0.77$ \\
\hline \multirow{2}{*}{\multicolumn{4}{|c|}{ Linolenic acid (LSD 5\% = 3.19) }} \\
\hline & & & \\
\hline Gulshan 98 & a $12.53 x \pm 1.53$ & b $8.03 y \pm 1.07$ & b $7.87 \mathbf{y} \pm 0.68$ \\
\hline Suncross & \multicolumn{2}{|c|}{ Oleic/linoleic (LSD $5 \%=0.19)$} & a $12.17 x \pm 1.10$ \\
\hline Gulshan 98 & a $1.78 x \pm 0.13$ & a $1.89 x \pm 0.05$ & b $2.38 x \pm 0.17$ \\
\hline Suncross & a $2.33 x \pm 0.02$ & b $2.60 x \pm 0.16$ & b $2.73 x \pm 0.18$ \\
\hline \multicolumn{4}{|c|}{ Total saturated fatty acids (LSD $5 \%=3.22$ ) } \\
\hline Gulshan 98 & a $16.75 x \pm 1.29$ & a $16.62 \times \pm 0.79$ & a $19.50 x \pm 0.58$ \\
\hline Suncross & a $13.45 \mathrm{y} \pm 0.72$ & b $16.94 x \pm 1.17$ & ab $16.44 x \pm 1.46$ \\
\hline \multicolumn{4}{|c|}{ Total unsaturated fatty acids (LSD $5 \%=4.74$ ) } \\
\hline Gulshan 98 & a $83.24 x \pm 5.29$ & a $82.04 x \pm 4.16$ & a $80.37 x \pm 3.56$ \\
\hline Suncross & a $86.90 \times \pm 3.68$ & a $83.61 x \pm 5.50$ & a $83.17 x \pm 4.10$ \\
\hline \multicolumn{4}{|c|}{ Alpha-tocopherol (LSD 5\% = 73.02) } \\
\hline Gulshan 98 & a $259.52 \mathrm{x} \pm 17.80$ & a 281.88 y \pm 8.52 & b 417.14 y \pm 19.14 \\
\hline Suncross & a $213.68 x \pm 8.67$ & b $430.59 x \pm 13.63$ & c $511.99 x \pm 25.84$ \\
\hline \multicolumn{4}{|c|}{ Delta-tocopherol (LSD 5\% = 7.11) } \\
\hline Gulshan 98 & b $42.62 x \pm 3.01$ & b $42.87 x \pm 4.32$ & a $101.39 x \pm 2.54$ \\
\hline Suncross & b $43.62 x \pm 2.20$ & b $38.47 x \pm 2.41$ & a $101.40 x \pm 2.54$ \\
\hline \multicolumn{4}{|c|}{ Gamma-tocopherol (LSD $5 \%=23.95$ ) } \\
\hline Gulshan 98 & a $38.33 x \pm 3.68$ & b $72.86 \mathbf{x} \pm 7.03$ & c $173.58 x \pm 7.51$ \\
\hline Suncross & a $51.24 x \pm 5.77$ & a $61.61 x \pm 6.54$ & b $180.05 x \pm 8.30$ \\
\hline \multicolumn{4}{|c|}{ Total tocopherols (LSD $5 \%=43.24)$} \\
\hline Gulshan 98 & a $340.48 x \pm 13.11$ & b $397.62 \mathbf{y} \pm 12.29$ & c 692.11 y \pm 27.22 \\
\hline Suncross & a $308.54 x \pm 10.08$ & b $530.67 x \pm 11.83$ & c $793.44 x \pm 25.65$ \\
\hline
\end{tabular}

Means sharing the same letters in horizontal rows $(a, b, c)$ and in columns $(x, y)$ do not show differences due to imposition of water stress at different growth stages and between cultivars, respectively.

LSD, least significant difference.

contents than Gulshan-98 under water stress conditions (Table 1).

The iodine value of the oil decreased significantly in cv. Suncross with the imposition of water stress at the reproductive stage, but this decreasing effect was not observed in cv. Gulshan98; however, the oil saponification value remained unaffected due to water stress (Table 2).

The unsaponifiable matter of the oil was significantly affected in both sunflower cultivars due to water stress applied at the reproductive stage. It decreased significantly in cv. Gushan-98 but in contrast, in cv. Suncross it increased under water stress conditions when imposed at the reproductive stage (Table 2). Other characteristics such as the density, specific gravity, and refractive index of the oil were not affected due to water stress imposed at either growth stage neither did the cultivars differ in these physical characteristics of the oil (Table 2).

\section{DISCUSSION}

Water availability is one of the major agronomy factors that can influence the production and quality of sunflower oil. In the present study, water stress caused a reduction in the oil content of both cultivars, which is in agreement with the results of Talha and Osman (1975) for sunflowers (Helianthus annuus L.).

In the present study, an increase in the oil's stearic acid concentration in Cv. Gulshan-98 under 
Table 2

Physico-chemical properties of the seed oil of two sunflower lines when subjected to water stress at different growth stages $(n=3)$

\begin{tabular}{|c|c|c|c|}
\hline & Normal irrigation & $\begin{array}{l}\text { Water stress } \\
\text { at vegetative stage }\end{array}$ & $\begin{array}{l}\text { Water stress } \\
\text { at reproductive stage }\end{array}$ \\
\hline \multicolumn{4}{|c|}{ lodine value (LSD $5 \%=10.12$ ) } \\
\hline Gulshan 98 & a $119.87 \mathrm{x} \pm 5.57$ & a $112.62 x \pm 4.56$ & a $112.08 x \pm 3.38$ \\
\hline \multicolumn{4}{|c|}{$\begin{array}{c}128.34 \times \pm 3.78 \quad \text { a } 119.10 \times \pm 2.52 \\
\text { Unsaponifiable matter (LSD } 5 \%=0.13 \text { ) }\end{array}$} \\
\hline Gulshan 98 & a $0.59 x \pm 0.01$ & a $0.70 x \pm 0.06$ & b 0.46 y \pm 0.05 \\
\hline Suncross & $\begin{array}{l}\text { a } 0.39 \text { y } \pm 0.01 \\
\text { Saponification }\end{array}$ & Saponification value (LSD 5\% = 8.92) & b $0.90 x \pm 0.06$ \\
\hline Gulshan 98 & a $184.42 \mathrm{x} \pm 4.56$ & a $185.01 x \pm 3.89$ & a $188.52 x \pm 4.89$ \\
\hline Suncross & a $185.49 x \pm 5.22$ & a $186.67 x \pm 4.56$ & a 178.45 y \pm 3.56 \\
\hline Gulshan 98 & $\begin{array}{r}\text { Refractive ind } \\
\text { a } 1.4637 \mathbf{x} \pm 0.0009\end{array}$ & \multicolumn{2}{|c|}{ Refractive index (LSD 5\% = 0.0028 ) } \\
\hline Suncross & a $1.4640 \mathrm{x} \pm 0.0006$ & a $1.4627 \times \pm 0.0009$ & a $1.4637 x \pm 0.0009$ \\
\hline \multicolumn{4}{|c|}{ Density (LSD $5 \%=0.035)$} \\
\hline Gulshan 98 & a $0.9467 \times \pm 0.01$ & a $0.9400 x \pm 0.01$ & a $0.9133 x \pm 0.01$ \\
\hline \multicolumn{4}{|c|}{ Specific gravity $($ LSD $5 \%=0.035)$} \\
\hline Gulshan 98 & a $0.9267 \times \pm 0.01$ & a $0.9200 x \pm 0.01$ & a $0.8933 x \pm 0.01$ \\
\hline Suncross & a $0.9333 x \pm 0.01$ & b $0.8767 \mathbf{y} \pm 0.01$ & a $0.9200 x \pm 0.02$ \\
\hline
\end{tabular}

Means sharing the same letters in horizontal rows $(a, b, c)$ and in columns $(x, y)$ do not show differences due to imposition of water stress at different growth stages and between cultivars, respectively.

LSD, least significant difference.

water stress imposed at the vegetative or the reproductive stage was observed, whereas no effect of drought was observed on its Palmitic acid content. The results of the present study showing an increase in the stearic acid content are in agreement with the findings of Flagella et al. (2002), who reported a significant increase in stearic acid contents of sunflower oil under water stress but it also resulted in an alternate decrease in palmitic acid content. The differences in the results of the two studies may be due to the imposition of drought at different growth stages because in the latter study the drought was imposed at the start of the experiment, whereas in the present study drought was imposed at either vegetative or reproductive stage.

In the present study the increase or decrease in oil oleic and linoleic acid contents due to waterstress when applied at different growth stages was cultivar specific. An increase in oleic acid with a subsequent decrease in linoleic acid was observed in cv. Gulshan-98, however; in cv. Suncross a decrease in oleic acid content and no effect on linoleic acid content was observed when water stress was applied at different growth stages. This effect of water stress on the content of oil oleic and linoleic acid may be attributed to the activity of the enzyme $\Delta 12$ desaturase (Baldini et al. 2000). Baldini et al. (2000) found that the increase in oleic acid was due to the activity of $\Delta 12$ desaturase, responsible for the conversion of oleic to linoleic acid, which was affected due to water stress (Baldini et al. 2000; Sobrino et al. 2003). Furthermore, the author reported that this enzyme acts only for a very short period during the early development of the embryo in water stressed plants. Secondly, while working with sunflowers, Sobrino et al. (2003) found a strong inverse relationship between oleic and linoleic acid contents and reported that the enzyme $\Delta 12$ desaturase is responsible for these responses. However, Salera and Baldini (1998) observed no effect of water management on oleic acid content. These contrasting results may be due to different environmental conditions under which the sunflowers were grown.

The change in the linolenic acid contents due to water stress was cultivar specific, which is evident from its reduction in Gulshan-98 only. Such a cultivar specific response to water stress with respect to linolenic acid content was not observed in two hybrids of sunflowers (Flagella et al., 2000). Furthermore, Connor and Sadras (1992) reported that fatty acid composition differs between cultivars due to changes in environmental conditions.

The oleic/linoleic ratio increased due to water stress imposed at different growth stages in the present study and a maximum increase was observed at the reproductive stage. This increase in oleic/linoleic is in agreement with the findings of Talha and Osman (1975) and Flagella et al. (2002), who demonstrated a clear tendency to increase the oleic/linoleic ratio under water stress, especially when plants were subjected to soil water stress during the elongation stage. Water stress applied during the grain filling period caused a significant increase in the oleic/linoleic ratio in high oleic genotypes of sunflowers grown in North-East Italy (Baldini et al., 2000). In contrast, Uger (1982) found very little differences in oleic/linoleic ratios in sunflower under different water regimes. 
In the present study, the contents of unsaturated fatty acids in both cultivars remained unchanged due to water stress applied at the vegetative or the reproductive stage but saturated fatty acids increased in cv. Gulshan-98. These results are not in agreement with those of Baldini et al. (2002) who reported that the saturated fatty acid contents (palmitic acid and stearic acid) in sunflower did not vary under different water regimes. These different responses of cultivars may be due to different environments as cultivars respond differently to different environments (Connor and Sadras, 1992). While working with sunflowers, Sobrino et al. (2003) found a balance between oleic and linoleic acids and strong inverse relationships were shown between their concentrations. It can be attributed to differential sensitivity of $\Delta 12$ desaturase, an enzyme responsible for the conversion of oleic to linoleic acid during embryo development, under water stress conditions (Lagravere et al., 2000).

The contents of total and individual tocopherols increased in sunflower oil due to water stress, particularly when water stress was applied at the reproductive stage. Furthermore, a positive correlation exists between oleic acid and tocopherol contents and a negative correlation between linoleic acid and tocopherol contents in the present study. These changes in tocopherol contents may therefore be due to a positive correlation between oleic acid and tocopherol and a negative correlation between linoleic and tocopherols as also reported by Baydar and Erbas (2005).

The iodine value as it represents the degree of un-saturation of the oil in the present study was slightly decreased due to water stress. Similar results were reported in Canada in flaxseed 2007 (Prairie Recommending Committee for Oilseeds). According to this report environmental stresses such as heat or drought generally cause a reduction in the oil contents and iodine values of flaxseed oil in most of the flax cultivars examined. In contrast, Anwar et al. (2006) reported no effect of drought on the iodine value of the Moringa oleifera seed oil.

The saponifiable matter of sunflower oil remained unchanged in the present study under water stressed conditions. These findings are similar to our work on Moringa oleifera oil where saponification value was not affected due to drought stress (Anwar et al. 2006). However, unsaponifiable matter decreased in the oil of cv. Gulshan-98 and increased in cv. Suncross under water stress imposed at the reproductive stage. These results are not in agreement with those found in Moringa oleifera seed oil (Anwar et al., 2006).

Other physical properties of the oil such as refractive index, density and specific gravity in the present study were not affected in both cultivars of sunflower when water stress was applied at different growth stages. Similarly, in another study drought stress did not affect these characteristics of Moringa olefera seed oil (Anwar et al., 2006).

\section{CONCLUSIONS}

From the results of these comprehensive analyses, it could be concluded that drought might be considered as one of the most visible factors which affects some of the constituents of the seed oil of both sunflower cultivars. The oil yield, fatty acid composition, oil tocopherol content, iodine value, and unsaponifiable matter are the distinctive parameters most vulnerable to drought. Cultivar differences were possible to discern on the basis of seed oil content, oleic acid, oleic/linoleic ratios, and individual and total tocopherol contents where they were higher in cv. Suncross than in cV. Gulshan-98.

\section{REFERENCES}

American Oil Chemist's Society (AOCS). 1997. Official Methods and Recommended Practices of the American Oil Chemists Society, $5^{\text {th }}$ Ed., AOCS Press, Champaign, IL, USA.

Anwar F, Zafar SN, Rashid U. 2006. Characterization of Moringa oleifera seed oil from drought and irrigated regions of Punjab, Pakistan. Grasas Aceites 57, 160168.

Baldini M, Giovanardi R, Vannozzi GP. 2000. Effects of different water availability on fatty acid composition of the oil in standard and high oleic sunflower hybrids, in Proceedings of 15th International Sunflower Conference, A.79-A.84. Toulouse, France, 12-15 June.

Baldini M, Giovanardi R, Tahmasebi-Enferadi S, Vannozzi GP. 2002. Effects of water regimes on fatty acid accumulation and final fatty acid composition in the oil of standard and high oleic sunflower hybrids. Ital. J. Agron. 6, 119-126.

Baydar H, Erbas S. 2005. Influence of seed development and seed position on oil, fatty acids and total tocopherol contents in sunflower (Helianthus annuus L.). Turk. J. Agric. Forest. 9, 179-186.

Connor DJ, Sadras VO. 1992. Physiology of yield expression in sunflower. Field Crops Res. 30, 333389.

Demurin Y, Skoric D, Karlovic D. 1996. Genetic variability of tocopherol composition in sunflower seeds as a basis of breeding for improved oil quality. Plant Breeding 115, 33-36.

Dewis J, Freitas F. 1970. Physical methods of soil and water analysis. FAO Soil Bull. No. 10, Rome, 39-51.

Flagella Z, Rotunno T, Caterina RD, Simone GD, Caro AD. 2000. Effect of supplementary irrigation on seed yield and oil quality of sunflower (Helianthus annuus L.) grown in a sub-arid environment, in: Proceedings of XV International Sunflower Conference, 139-144, 1, Toulouse.

Flagella Z, Rotunno T, Tarantito E, Caterina RD, Caro AD. 2002. Changes in seed yield and oil fatty acid composition of high oleic sunflower (Helianthus annuus L.) hybrids in relation to the sowing date and the water regime. Eur. J. Agron. 17, 221-230.

International Union of Pure and Applied Chemistry. 1987. Standard Methods for the Analysis of Oils, Fats and Derivatives, 7th Rev. Ed., Paquot C. Hautfenne A. Eds., Blackwell Scientific, London, UK. 
Kefale D, Ranamukhaarachchi SL. 2006. Response of maize varieties to drought stress at different phenological stages in Ethiopia. Tropical Sci. 44, 61-66.

Lagravere T, Lacombe S, Surel O, Kleiber D, Berville A, Dayde J. 2000. Oil composition and accumulation of fatty acids in new oleic sunflower (Helianthus annuus L.) hybrids. in: Proceedings of XV International Sunflower Conference, A25-30, Toulouse.

Lee BI, New AL, Ong CN. 2003. Simultaneous determination of tocotrienols, tocopherols, retinols and major carotenoids in human plasma. Clin. Chem. 49, 2056-2066.

Li-Ping B, Fang-Gong S, Ti-Da G, Zhao-Hui S, Yin-Yan L, Guang-Sheng Z. 2006. Effect of soil drought stress on leaf water status, membrane permeability and enzymatic antioxidant system of Maize. Pedosphere 16, 326-332.

Monotti M. 2003. Growing non-food sunflower in dryland conditions. Ital. J. Agron. 8, 3-8.

MSTAT Development Team. MSTAT user's guide: 1989. A microcomputer program for the design management and analysis of agronomic research experiments, Michigan State Univ. East Lansing, IL.

Nam N H, Chauhan YS, Johansen C. 2001. Effect of timing of drought stress on growth and grain yield of extra-short-duration pigeon pea lines. J. Agric. Sci. 136, 179-189.

Nel AA. 2001. Determination of sunflower seed quality for processing, Ph.D Thesis. Dept. of Plant Production and Soil Sciences. University of Pretoria, Pretoria, South Africa, pp. 40-56.
Prairie Recommending Committee for Oilseeds, "Minimum Standards for Linseed Flax Cultivar Registration 2007", pp. 47 of the Report of Flax Cooperative Test 2007.

Salera E, Baldini M. 1998. Performance of high and low oleic acid hybrids of sunflower under different environmental conditions. Note I/ Helia 21. 28, 55-68.

Santonoceto C, Anastasi A, Riggu U, Abbate EV. 2003. Accumulation dynamics of dry matter, oil and major fatty acids in sunflower seeds in relation to genotype and water regime. Ital. J. Agron. 7, 3-14.

Slover HT. 1970. Tocopherols in foods and fats. Lipids 6 , 291-296.

Sobrino E, Tarquis AM, Diaz MC. 2003. Modeling the oleic acid content in sunflower oil. Agron. J. 95, 329334

Steel RGD, Torrie JH. 1986. Principles and procedures of statistics. McGraw Hill Book Co., Inc. New York, NY.

Talha M, Osman F. 1975. Effect of soil water stress on water economy and oil composition in sunflower (Helianthus annuus L.). J. Agric. Sci. 84, 49-56.

Unger PW. 1982. Time and frequency of irrigation effects on sunflower production and water use. Soil Sci. Soc. Am. J. 46, 1072-1076.

Vermeersch G. 1996. Industrial uses of sunflower oil. OCL. I, 19-21. 